\title{
Pengolahan Citra Digital Dalam Penentuan Panen Jamur Tiram
}

\author{
Dedy Ega Saputra \\ Program Studi Teknik Elektro, \\ Fakultas Teknik Universitas Trunojoyo \\ Madura, \\ Bangkalan, Indonesia \\ dedy.ega.saputra@gmail.com
}

\author{
Diana Rahmawati \\ Program Studi Teknik Elektro, \\ Fakultas Teknik Universitas Trunojoyo \\ Madura, \\ Bangkalan, Indonesia \\ diana_rahmawti@yahoo.com
}

\author{
Achmad Fiqhi Ibadillah \\ Program Studi Teknik Elektro, \\ Fakultas Teknik Universitas Trunojoyo \\ Madura, \\ Bangkalan, Indonesia \\ fiqhi.achmad@gmail.com
}

\begin{abstract}
Saat ini teknologi telah berkembang sangat pesat dan hal itu mulai memodernisasi beberapa bidang kegiatan manusia di era ini. Bidang pertanian pun tak luput dari perkembangan teknologi untuk hal penelitian. Deteksi objek merupakan salah satu teknologi yang terus dikembangkan dan diteliti hingga saat ini. Pada Tugas Akhir ini akan dibahas Pengolahan Citra Digital Dalam Penentuan Panen Jamur Tiram. Dalam penelitian ini digunakan metode deteksi tepi Canny dan kontur. Hasil penelitian ini akan didapat data penentuan panen dan kualitas jamur tiram.
\end{abstract}

Kata Kunci-teknologi, deteksi, jamur tiram, Canny.

\section{PENDAHULUAN}

Jamur Tiram putih (Pleurotus ostreatus) adalah jenis jamur kayu yang memiliki kandungan nutrisi yang lebih tinggi dibandingkan dengan jenis jamur kayu lainnya, didalam jamur tiram putih terkandung protein, lemak, fosfor, besi, thiamin, dan riboflavin yang lebih tinggi dibandingkan jenis jamur lain (Nunung, 2001) [1]. Dibuktikan oleh (Sumarni,2006), bahwa setiap 100 gram jamur tiram mengandung protein $19-35 \%$ dengan 9 macam asam amino, lemak 1,7\%-2,2\% terdiri dari $72 \%$ asam lemak tak jenuh. Sedangkan karbohidrat dalam jamur tiram terdiri dari tiamin, riboflavin, dan niasin merupakan vitamin B utama dalam jamur tiram, selain vitamin $\mathrm{D}$ dan $\mathrm{C}$ mineralnya terdiri dari $\mathrm{K}, \mathrm{P}, \mathrm{Na}, \mathrm{Ca}, \mathrm{Mg}, \mathrm{Zn}, \mathrm{Fe}, \mathrm{Mn}, \mathrm{Co}$, dan Pb.

Mikroelemen dalam jamur tiram yang bersifat logam sangat rendah sehingga aman dikonsumsi setiap hari [2]. Panen jamur tiram pada satu media tanam dapat dilakukan beberapa kali. Media tanam dengan ukuran \pm 800 dapat dipanen 4-5 kali. Jarak waktu antara panen pertama dan kedua secara umum terjadi antara 7-14 hari, kecepatan pertumbuhan tersebut juga sangat dipengaruhi oleh kondisi lingkungan tempat pertumbuhan jamur yang digunakan. Oleh karena itu dalam pemanenan perlu memperhatikan beberapa hal antara lain penentuan saat panen dan teknik pemanenan itu sendiri. Panen dapat dilakukan pada saat jamur mencapai pertumbuhan yang optimal, yakni ukurannya cukup besar, tetapi tudungnya belum mekar penuh (ditandai pada bagian pinggir tudung jamur masih terlihat utuh/belum pecah). Ukuran diameter jamur yang siap panen rata - rata mencapai $5-10 \mathrm{~cm} \mathrm{[3].}$

Seiring dengan kemajuan teknologi komputer, penggunaan computer vision untuk pembelajaran menganalisis gambar atau video untuk mendapatkan hasil sebagaimana yang bias dilakukan manusia serta pada hakikatnya, computer vision mencoba meniru cara kerja sistem visual manusia (Human vision). Tujuan penelitian ini dilakukan untuk mengukur dan menganalisa bagaimana penerapan metode deteksi tepi Canny pada pengolahan citra digital terhadap penentuan panen jamur tiram.

\section{BAHAN DAN METODE}

Metode penelitian meliputi perancangan dan pengujian, perancangan sistem Delphi XE 7.

\section{A. Diagram Blok Sistem}

Pada perancangan alat tugas akhir ini terdapat beberapa tahapan agar perencanaan sesuai dengan yang diharapkan. Berikut rancengan sistem dalam bentuk diagram blok.

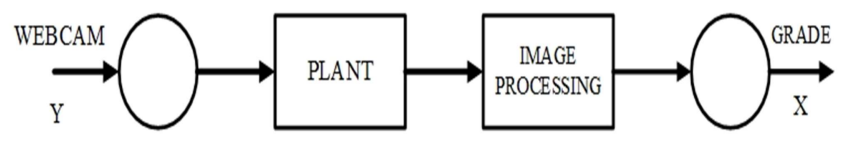

Gambar 1.1 Blok Diagram Sistem

Pada perancangan tugas akhir ini terdapat tahapan agar perencanaan yang akan dilaksanakan sesuai dengan yang diharapkan. Dari gambar blok diagram diatas dijelaskan bahwa terdapat sebuah kamera yang dipasang diatas objek, ketika jamur tiram terdeteksi oleh kamera maka akan diolah dengan image processing menggunakan deteksi tepi Canny dan kontur. Deteksi tepi Canny digunakan untuk mengetahui batas tepi dari objek jamur tiram sedangkan kontur digunakan untuk menyimpan titik- titik kontur dalam menghitung luas dan menentukan grade yang telah ditentukan untuk mengetahui hasil akhir jamur tiram dalam grade $\mathrm{A}$ atau $\mathrm{B}$.

\section{B. Alat dan Bahan}

\section{Kamera WebCam}

WebCam merupakan gabungan dari kata web dan camera. Webcam sendiri sebutan untuk kamera real time yang dapat diakses atau dilihat melalui internet dan lainnya. Webcam biasanya digunakan untuk keperluan jarak jauh atau juga digunakan sebagai kamera pemantau.

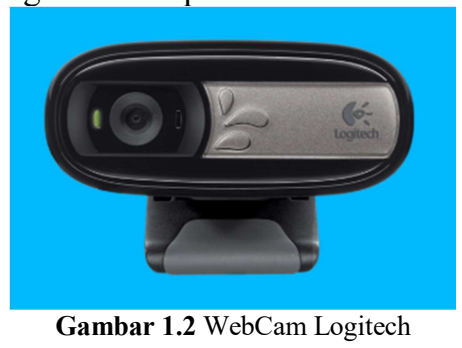

Spesifikasi Logitech C170

- $\quad$ Panggilan video (640x480 piksel)

- $\quad$ Merekan video hingga 1024x768 piksel

- Teknologi Logitech Fluid Crystal

- $\quad$ Hi-Speed USB 2.0

2. Laptop 
Laptop merupakan komputer bergerak (dapat dipindah - pindah dengan mudah) dengan ukuran relatif kecil dan ringan, beratnya berkisar dari 1-6 kg, tergantung ukuran, bahan, dari spesifikasi laptop tersebut. Laptop memiliki baterai yang memungkinkan untuk beroperasi tanpa terhubung ke stopkontak.

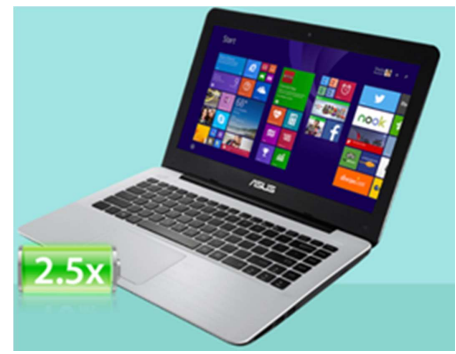

Gambar 1.3 Laptop ASUS X455L

Spesifikasi ASUS X455L

- $\quad$ Processor Intel Core i3 5010U 2.10Ghz

- $\quad$ RAM 6 GB

- HDD $500 \mathrm{~GB}$

- Intel HD Graphic 5000

3. Konversi Grayscale

Adapun persamaan yang digunakan untuk menkonversi citra berwarna mejadi citra grayscale adalah sebagai berikut:

$\left.f_{0}(x, y)=\left(\frac{f_{R}(x, y)+f_{G}(x, y)+f_{B}(x, y)}{3}\right)\right)$

Dimana:

$f_{0}$ adalah nilai komponen red

$f_{G}$ adalah nilai komponen green

$f_{B}$ adalah nilai komponen blue

\section{Thresholding}

Proses thresholding merupakan suatu proses mengubah citra grayscale menjadi suatu citra biner. Secara matematis dapat ditulis sebagai berikut :

$$
g(x, y)=\left\{\begin{array}{l}
1 \text { if } f(x, y) \geq T \\
0 \text { if } f(x, y) \leq T
\end{array}\right.
$$

Dengan $g(x, y)$ adalah citra biner dari citra grayscale $\mathrm{f}(\mathrm{x}, \mathrm{y})$ dan $\mathrm{T}$ adalah nilai threshold.

\section{Deteksi Tepi Canny}

Salah satu operator deteksi tepi adalah deteksi tepi Canny yang dikembangkan oleh John F. Canny. Ada beberapa kriteria deteksi tepi paling optimum dengan algoritma Canny yaitu mendeteksi dengan baik (kriteria deteksi), melokalisasi dengan baik (kriteria lokalisasi), respon yang jelas (kriteria respon).

Langkah pertama adalah dengan menghilangkan noise yang terdapat pada citra dengan mengimplemntasikan filter Gaussian. Berikut adalah salah satu contoh filter Gaussian dengan $\sigma=14$

$$
\frac{1}{115}\left[\begin{array}{ccccc}
2 & 4 & 5 & 4 & 2 \\
4 & 9 & 12 & 9 & 4 \\
5 & 12 & 15 & 12 & 5 \\
4 & 9 & 12 & 9 & 4 \\
2 & 4 & 5 & 4 & 2
\end{array}\right]
$$

Langkah kedua yaitu melakukan deteksi tepi salah satu operator deteksi tepi seperti Roberts,Prewitt dan
Sobel dengan melakukan pencarian horizontal (G_x ) dan secara vertikal (G_y), berikut adalah salah satu contoh operator deteksi tepi (operator sobel).

Besarnya gradient atau kuatnya tepi kemudian didekati dengan menggunakan rumus :

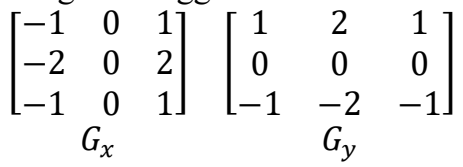

Besarnya gradient atau kuatnya tepi kemudian didekati dengan menggunakan rumus :

$$
|G|=\left|G_{x}\right|+\left|G_{y}\right|
$$

Langkah ketiga yaitu dengan menentukan arah tepian menggunakan rumus :

$$
\theta=\arctan \left(\frac{G_{y}}{G_{x}}\right)
$$

Langkah ke empat yaitu dengan memperkecil garis tepi yang muncul dengan menerapkan Non Maximum Suppression sehingga menghasilkan garis tepian yang lebih ramping.

Langkah terakhir adalah binerisasi dengan menerapkan dua buah nilai ambang. Gambar berikut ini menunjukkan bentuk citra sebelum pemrosesan dan sesudah mengalami pemprosesan. Langkah terakhir adalah binerisasi dengan menerapkan dua buah nilai ambang/tresholding. Gambar berikut ini menunjukkan bentuk citra sebelum pemrosesan dan sesudah pemprosesan.
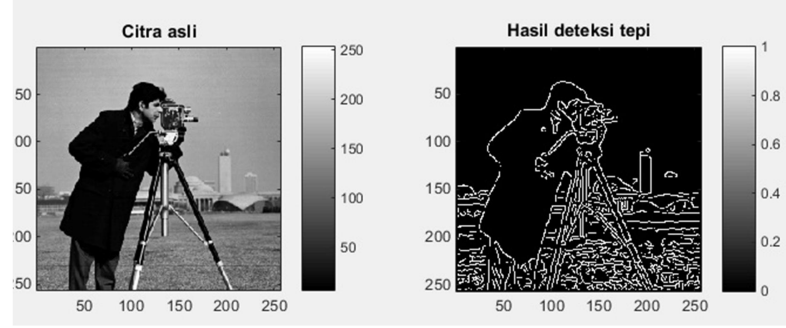

Gambar 1.4 Hasil Pemrosesan Citra

\section{Kontur (Contour)}

Pendeteksian tepi akan menghasilkan citra tepi yang berupa citra biner (pixel tepi berwarna putih, sedangkan pixel bukan tepi berwarna hitam). Tetapi, tepi belum memberikan informasi yang berguna karena belum terdapat keterkaitan antara suatu tepi dengan tepi lainya. Citra tepi ini harus diproses lebih lanjut untuk menghasilkan informasi yang lebih berguna yang dapat digunakan dalam mendeteksi bentuk-bentuk yang sederhana (misalnya garis lurus, lingkaran, elips, dan sebagainya) pada proses analisis citra.

Rangkaian dari pixel-pixel tepi yang membentuk batas daerah (region boundary) disebut kontur (Contour). Kontur dapat terbuka atau tertutup. Kontur tertutup berkoresponden dengan batas yang mengelilingi suatu daerah lihat pada Gambar 1.4. (a).
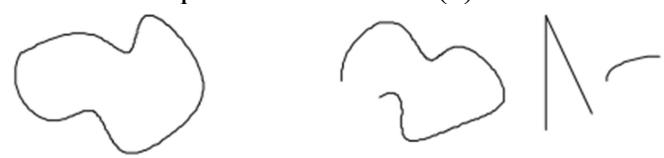

Gambar 1.4 (a) kontur tertutup, (b) kontur terbuka

pixel-pixel didalam daerah dapat ditemukan dengan algoritma pengisian (filling algorithm). Batas daerah 
berguna untuk mendeskripsikan bentuk objek dalam tahap analisi citra (misalnya untuk mengenali objek).Kontur terbuka dapat berupa fragmen garis atau bagian dari batas daerah yang tidak membentuk sirkuit (Gambar 1.4. (b)).

\section{Flow Chart Sistem}

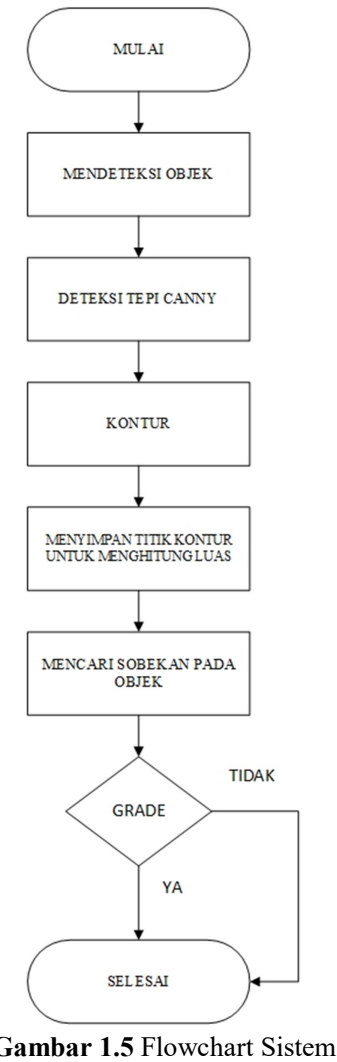

Gambar diatas menjelaskan alur flowchart, dengan penjelasan sebagai berikut :

- Pada keadaan awal melakukan proses capture gambar objek jamur tiram.

- Melakukan proses deteksi tepi dan kontur terhadap objek jamur tiram

- Mencari titik tengah objek jamur tiram kemudian menghitung diameter objek.

\section{HASIL DAN PEMBAHASAN}

Sistem penentuan panen dan kualitas jamur tiram diawali dengan mengcapture objek jamur tiram dengan webcam. Software yang digunakan dalam penelitian ini adalah Embarcadero Delphi XE 7 yang diolah dengan metode deteksi tepi Canny dan kontur, kemudian akan didapatkan hasil berupa ukuran jamur tiram dalam (piksel/cm), kategori jamur tiram, dan hasil penentuan panen jamur tiram.
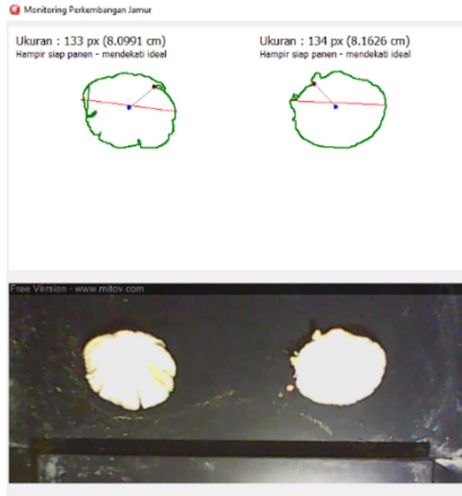

Gambar 2.1 Hasil capture jamur tiram

Objek hijau merupakan hasil dari pemrosesan citra objek, dan garis merah digunakan untuk menentukan titik tengah objek.

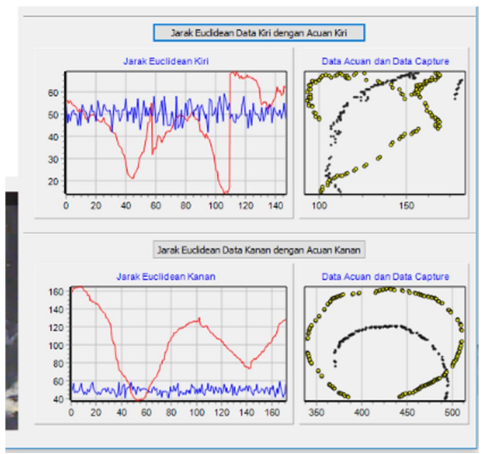

Gambar 3.2 Hasil grafik dan data acuan jamur kecil

Garis biru merupakan grafik acuan objek, garis merah merupakan grafik pembanding objek, titik kuning sebagai data acuan objek dan titik hitam sebagai data capture objek.

Hasil pengujian terhadap beberapa sampel jamur tiram yaitu sebagai berikut.

TABEL 1 Hasil PenguJian OBJeK DI SEKTOR KIRI

\begin{tabular}{|c|c|c|c|c|}
\hline NO. & $\begin{array}{c}\text { Ukuran pada } \\
\text { aplikasi } \\
(\mathrm{px} / \mathrm{cm})\end{array}$ & Kategori & $\begin{array}{c}\text { Kualita } \\
\mathrm{s}\end{array}$ & Hasil \\
\hline 1. & $100 / 6,09$ & HI & $\mathrm{A}$ & HSP \\
\hline 3. & $120 / 7,3$ & $\mathrm{I}$ & $\mathrm{A}$ & $\mathrm{SP}$ \\
\hline 5. & $125 / 7,6$ & $\mathrm{I}$ & $\mathrm{B}$ & $\mathrm{SP}$ \\
\hline 7. & $110 / 6,6$ & $\mathrm{I}$ & $\mathrm{A}$ & $\mathrm{SP}$ \\
\hline 9. & $116 / 7,1$ & $\mathrm{I}$ & $\mathrm{A}$ & $\mathrm{SP}$ \\
\hline 11. & $97 / 5,9$ & $\mathrm{HI}$ & $\mathrm{A}$ & $\mathrm{HSP}$ \\
\hline 13. & $106 / 6,4$ & $\mathrm{I}$ & $\mathrm{A}$ & SP \\
\hline 15. & $86 / 5,0$ & HI & $\mathrm{A}$ & HSP \\
\hline 17. & $94 / 5,7$ & HI & B & HSP \\
\hline 19. & $73 / 4,4$ & S & B & BSP \\
\hline
\end{tabular}


Tabel 2. Perbandingan Pengukuran Menggunakan

\begin{tabular}{|c|c|c|c|}
\hline NO. & $\begin{array}{r}\text { Ukuran } \\
\text { pada } \\
\text { aplikasi (cm) }\end{array}$ & $\begin{array}{r}\text { Ukuran Nyata } \\
(\mathrm{cm})\end{array}$ & Margin \\
\hline 1. & 6,09 & 6 & 0,09 \\
\hline 3. & 7,3 & 7.5 & 0,2 \\
\hline 5. & 7,6 & 7.5 & 0,1 \\
\hline 7. & 6,6 & 6.5 & 0,1 \\
\hline 9. & 7,1 & 7 & 0,1 \\
\hline 11. & 5,9 & 6 & 0,1 \\
\hline 13. & 6,4 & 6.5 & 0,1 \\
\hline 15. & 5,0 & 5 & 0,3 \\
\hline 17. & 5,7 & 6 & 0,4 \\
\hline 19. & 4,4 & 4 & \\
\hline
\end{tabular}

Berdasarkan Tabel nilai toleransi antara aplikasi dengan mistar dapat diperoleh dengan menghitung nilai rata - rata margin yaitu :

Rata - Rata $=\frac{\sum \text { Nilai Data }}{\text { Banyaknya Data }}$

$=\frac{0,09+0,2+0,1+0,1+0,1+0,1+0,1+0+0,3+0,4}{10}$

$=0,149$

Dengan menggunakan toleransi 0,149Dari data Tabel diatas, diketahui dari 10 kali uji sampel jamur tiram yang dilakukan, sistem mengalami kegagalan sebanyak 3. Dengan menggunakan image processing didapat presentasi keberhasilan sebesar :

Total Pengujian : 10, Berhasil 7, Gagal 3.

Precision $=\frac{\text { Berhasil }}{\text { Berhasil }+ \text { Gagal }} \times 100 \%$

$$
=\frac{7}{7+3} \times 100 \%=0,7=70 \%
$$

Accuracy $=\frac{\text { Berhasil }+ \text { Total }_{p}}{\text { Berhasil }+ \text { Gagal }+ \text { Total }_{p}} \times 100 \%$

$$
=\frac{7+10}{7+3+10} \times 100 \%=\frac{17}{20} \times 100 \%=85 \%
$$

Error Rate $=\frac{\text { Gagal }}{\text { Berhasil }+ \text { Gagal }+ \text { Total }_{p}} \times 100 \%$

$$
=\frac{3}{7+3+10} \times 100 \%=0,15=15 \%
$$

Tabel 3 Hasil Pengujian ObJeK di SeKToR

KANAN

\begin{tabular}{|c|c|c|c|c|}
\hline NO. & $\begin{array}{c}\text { Ukuran pada } \\
\text { aplikasi }(\mathrm{cm})\end{array}$ & Kategori & Kualitas & Hasil \\
\hline 1. & $98 / 5,9$ & HI & B & HSP \\
\hline 2. & $96 / 5,8$ & HI & A & HSP \\
\hline 3. & $80 / 4,8$ & S & A & BSP \\
\hline 4. & $128 / 7,7$ & I & B & SP \\
\hline 5. & $96 / 5,8$ & HI & B & HSP \\
\hline 6. & $94 / 5,6$ & HI & A & HSP \\
\hline 7. & $72 / 4,3$ & S & A & BSP \\
\hline 8. & $107 / 6,5$ & I & A & SP \\
\hline 9. & $74 / 4,4$ & S & B & BSP \\
\hline 10. & $104 / 6,3$ & I & A & SP \\
\hline
\end{tabular}

Tabel 4. Perbandingan Pengukuran MenggunaKan

\section{APLIKASI DAN MISTAR}

\begin{tabular}{|c|c|c|c|}
\hline NO. & $\begin{array}{c}\text { Ukuran pada } \\
\text { aplikasi (px/cm) }\end{array}$ & $\begin{array}{c}\text { Ukuran } \\
\text { Nyata } \\
(\mathrm{cm})\end{array}$ & Margin \\
\hline 1. & 5,9 & 6.4 & 0,5 \\
\hline 2. & 5,8 & 6 & 0,2 \\
\hline 3. & 4,8 & 5 & 0,2 \\
\hline 4. & 7,7 & 7.5 & 0,2 \\
\hline 5. & 5,8 & 5.5 & 0,3 \\
\hline 6. & 5,6 & 5.5 & 0,1 \\
\hline 7. & 4,3 & 4.5 & 0,2 \\
\hline 8. & 6,5 & 6 & 0,5 \\
\hline 9. & 4,4 & 4 & 0,4 \\
\hline 10. & 6,3 & 6.5 & 0,2 \\
\hline
\end{tabular}

$$
\begin{aligned}
& \text { Rata }- \text { Rata }=\frac{\sum \text { Nilai Data }}{\text { Banyaknya Data }} \\
& =\frac{0,5+0,2+0,2+0,2+0,3+0,1+0,2+0,5+0,4+0,2}{10} \\
& =0,28
\end{aligned}
$$

Dengan menggunakan toleransi 0,28

Dari data Tabel diatas, diketahui dari 10 kali uji sampel jamur tiram yang dilakukan, sistem mengalami kegagalan sebanyak 4. Dengan menggunakan image processing didapat presentasi keberhasilan sebesar :

Total Pengujian : 10, Berhasil 6, Gagal 4.

$$
\begin{aligned}
\text { recision } & =\frac{\text { Berhasil }}{\text { Berhasil }+ \text { Gagal }} \times 100 \% \\
& =\frac{6}{6+4} \times 100 \%=0,6=60 \%
\end{aligned}
$$




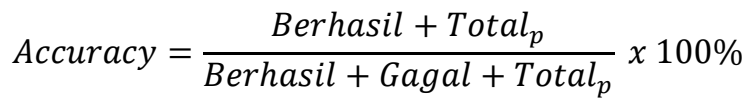

$$
\begin{aligned}
& =\frac{6+10}{6+4+10} \times 100 \%=\frac{16}{20} \times 100 \%=80 \% \\
& \text { Error Rate }=\frac{\text { Gagal }}{\text { Berhasil }+ \text { Gagal }+ \text { Total }_{p}} \times 100 \% \\
& =\frac{4}{6+4+10} \times 100 \%=0,2=20 \%
\end{aligned}
$$

\begin{tabular}{|c|c|}
\hline KODE & KETERANGAN \\
\hline S & Sedang \\
\hline HI & Hampir Ideal \\
\hline I & Ideal \\
\hline BSP & Belum Siap Panen \\
\hline HSP & Hampir Siap Panen \\
\hline SP & Siap Panen \\
\hline
\end{tabular}

Dari perhitungan tingkat keberhasilan sektor kiri didapat hasil precision sebesar $70 \%$ dari 10 sampel percobaan, kemudian untuk tingkat accuracy diperoleh hasil 85\%dari 10 sampel hasil percobaan yang dilakukan, dan tingkat error yang didapat sebesar $15 \%$. Untuk sektor kanan didapat hasil precision sebesar $60 \%$ dari 10 sampel percobaan, kemudian untuk tingkat accuracy diperoleh hasil 80\%dari 10 sampel hasil percobaan yang dilakukan, dan tingkat error yang didapat sebesar $20 \%$. Kesalahan pengukuran yang dilakukan oleh sistem citra dikarenakan oleh beberapa faktor eksternal. Diantaranya adalah cahaya ruangan maupun cahaya matahari di sekitar area pengambilan data. Apabila terdapat cahaya yang terlalu terang, maka sistem akan membaca cahaya sebagai objek jamur karena memiliki ruang warna yang sama, warna putih.

\section{KESIMPULAN}

Kesimpulan dari hasil penelitian dijelaskan pada bagian ini : 1. Cahaya sangat mempengaruhi tingkat akurasi sistem, apabila tingkat cahaya cukup baik maka sistem dapat bekerja secara optimal. Namun apabila cahaya berlebih maka keakurasian sistem dapat terganggu.

2. Penempatan kamera sangat berpengaruh pada akurasi sistem, sudut pengambilan gambar yang tepat akan memberikan hasil yang maksimal pada sistem.

3. Pada penelitian diperoleh hasil yang maksimal pada pengujian sektor kiri dengan tingkat presentasi precision, presentasi recall, presentasi accuracy data sektor kiri yang menunjukkan hasil lebih baik daripada sektor kanan.

\section{DAFTAR PUSTAKA}

[1] Nunung, M. D. 2001. Budidaya Jamur Tiram. Yogyakarta: Kanisi

[2] Sumarni. 2006. Botani dan Tinjauan Gizi Jamur Tiram Putih. Jurnal Inovasi Pertanian

[3] http://masrodji.blogspot.co.id/2010/12/panen-dan-penanganan-pascapanen-jamur.html 16/1/17
[4] Umam Khairul, SN Benny. 2016. Deteksi Obyek Manusia Pada Basis Data Video Menggunakan Metode Background Subtraction Dan Operasi Morfologi. Jurnal CoreIT. Vol.2, No. 2.

[5] Maulana Rizqy, Fitriyah Hurriyatul, Prakasa Esa. 2018. Implementasi Sistem Deteksi Slot Parkir Mobil Menggunakan Metode Morfologi dan Background Subtraction. Jurnal Pengembangan Teknologi Informasi dan Ilmu Komputer. Vol.2 No.5.

[6] Soeleman Moch Arief, AP Ricardus, NA Pulung. 2014. Background Subtraction Berbasis Algorithma K-Means Klastering untuk Deteksi Objek Bergerak. SEMANTIK.

[7] Irianto, Kurniawan Dwi. 2010. Pendeteksi Gerak berbasiskan Kamera Menggunakan OpenCV pada Ruangan. Surakarta: KomuniTi Universitas Muhammadiah Surakarta.

[8] http://wimsonevel.blogspot.co.id/2014/03/pengenalan-grafikakomputer.html.

[9] Kadir, Abdul. 2012. Teori dan Aplikasi Pengolahan Citra. Yogyakarta: Penerbit ANDI.

[10] Fifi. 2011. Pengukuran Kecepatan Obyek Bergerak Menggunakan Webcam Berbasis Pengolahan Citra Digital. Surabaya: Jurusan Matematika FMIPA Institut Teknologi Sepuluh November. 